\title{
KEANEKARAGAMAN HYMENOPTERA PARASITOID PADA PERKEBUNAN KELAPA SAWIT PTPN VIII CINDALI, BOGOR
}

\author{
Ichsan Luqmana Indra Putra ${ }^{1}$, Pudjianto ${ }^{2}$, \& Nina Maryana ${ }^{2}$ \\ ${ }^{1}$ Pascasarjana Entomologi, Institut Pertanian Bogor \\ ${ }^{2}$ Departemen Proteksi Tanaman, Fakultas Pertanian, Institut Pertanian Bogor \\ Jl. Kamper Kampus IPB Dramaga, Bogor, 16680 \\ E-mail: ichsanluqmana@gmail.com
}

\begin{abstract}
Diversity of parasitic Hymenoptera in PTPN VIII oil palm plantation Cindali, Bogor. One group of important natural enemies in oil palm plantation is parasitic Hymenoptera. The purpose of this research is to know the diversity and fluctuation of parasitic Hymenoptera PTPN VIII Cindali oil palm plantation. This research was conducted in 6 blocks of oil palm in September 2014 - June 2015. There were 5 plots in every observation blocks $39.2 \times 39.2 \mathrm{~m}$ in size, and used direct and indirect method. Direct method done by 5 plants in every plots was taken randomized to observed and taken the herbivore insects to reared until the parasitic Hymenoptera came out. Observation of cover crops conducted by 3 subplots determined diagonally in every plots $9.8 \times 9.8 \mathrm{~m}$ in size and herbivore insects was observed and collected. Indirect methods used sweep net and yellow pan trap. The result of this research, 26 parasitic Hymenoptera families was found, with the Braconidae was the most morphospecies found and the most individual amount was Scelionidae. The abundance of parasitoid in every month fluctuated.
\end{abstract}

Key words: diversity, fluctuation, parasitoid

\begin{abstract}
ABSTRAK
Keanekaragaman Hymenoptera parasitoid pada perkebunan kelapa sawit PTPN VIII Cindali, Bogor. Salah satu musuh alami penting yang terdapat pada area perkebunan kelapa sawit adalah Hyemenoptera parasitoid. Beberapa faktor yang memengaruhi keanekaragaman dan kelimpahan Hymenoptera parasitoid di lapang adalah ketersediaan inang dan keanekaragaman tanaman. Penelitian ini bertujuan melihat keanekaragaman dan fluktuasi Hymenoptera parasitoid yang berada pada area perkebunan kelapa sawit PTPN VIII Cindali. Penelitian dilakukan pada perkebunan kelapa sawit PTPN VIII Cindali, dengan menggunakan 6 blok kelapa sawit dan dilakukan dari September 2014 - Juni 2015 dengan pengamatan sebulan sekali. Pada setiap blok terdapat 5 plot yang berukuran 39,2 x 39,2 m, dengan menggunakan metode secara langsung dan tidak langsung. Metode secara langsung dilakukan dengan cara setiap blok diambil 5 tanaman secara acak untuk diamati dan diambil serangga herbivora untuk dipelihara sampai keluar parasitoidnya. Pengamatan vegetasi bawah ditentukan 3 subplot berukuran 9,8 x 9,8 $\mathrm{m}$ yang diambil secara diagonal. Pengamatan dan pengambilan serangga herbivora dilakukan di dalam subplot tersebut. Metode tidak langsung dengan menggunakan sweepnet dan perangkap kuning. Hasil penelitian ditemukan 26 famili Hymenoptera parasitoid, dengan morfospesies terbanyak adalah famili Braconidae dan jumlah individu terbanyak adalah famili Scelionidae. Kelimpahan populasi Hymenoptera parasitoid pada setiap bulan mengalami fluktuasi.
\end{abstract}

Kata kunci: fluktuasi, keanekaragaman, parasitoid

\section{PENDAHULUAN}

Kelapa sawit merupakan salah satu tanaman perkebunan yang mempunyai peranan penting dalam perekonomian Indonesia yaitu sebagai penghasil devisa non migas (PDI, 2007). Salah satu perusahaan perkebunan kelapa sawit di Indonesia yang merupakan Badan Usaha Milik Negara (BUMN) adalah PT Perkebunan Nusantara (PTPN) VIII. PTPN VIII memiliki beberapa kebun kelapa sawit yang tersebar di berbagai wilayah di Jawa Barat, dan salah satunya terdapat di Cindali, Kecamatan Ranca Bungur, Kabupaten Bogor. Beberapa penelitian mengenai serangga sudah pernah dilakukan di perkebunan sawit PTPN VIII, di antaranya tentang kumbang penyerbuk Elaeidobius kamerunicus Faust (Ayuningsih, 2013) dan keanekaragaman serangga pengunjung bunga jantan kelapa sawit (Kusumawardhani, 2011). Namun penelitian mengenai keanekaragaman Hymenoptera parasitoid di perkebunan tersebut belum pernah dilaporkan. Penggunaan parasitoid memiliki beberapa kelebihan dibandingkan dengan teknik pengendalian 
lainnya, yaitu mampu mengendalikan hama secara spesifik dan populasi parasitoid di lapangan relatif tinggi (Godfray, 1994).

Beberapa penelitian tentang Hymenoptera parasitoid pada perkebunan kelapa sawit telah dilakukan. Syed \& Shaleh (2003) menyatakan bahwa parasitoid Apanteles sp. (Hymenoptera: Braconidae) ditemukan menyerang larva Mahasena corbetti Tams (Lepidoptera: Psychidae) dengan tingkat parasitasi mencapai $60 \%$. Sahari (2012) melaporkan bahwa di Kalimantan Tengah, Hymenoptera parasitoid famili Braconidae ditemukan memarasiti larva Darna trima Moore (Lepidoptera: Limacodidae) yang merupakan hama tanaman kelapa sawit dengan tingkat parasitasi mencapai $60 \%$. Hymenoptera parasitoid yang terdapat pada pertanaman kelapa sawit adalah famili Aphelinidae, Bethylidae, Braconidae, Chalcididae, Diapriidae, Elasmidae, Encyrtidae, Eucharitidae, Eulophidae, Eupelmidae, Eurytomidae, Evaniidae, Gasteruptiidae, Ichneumonidae, Mymaridae, Mymarommatidae, Platygastridae, Pteromalidae, Scelionidae, dan Trichogrammatidae (Hindarto, 2015).

Mengingat pentingnya peranan Hymenoptera parasitoid, maka penelitian tentang keanekaragaman Hymenoptera parasitoid ini perlu dilakukan di perkebunan kelapa sawit PTPN VIII Cindali, sebagai kajian awal dalam pemanfaatannya sebagai agensia pengendalian hayati. Penelitian bertujuan (1) mengetahui keanekaragaman Hymenoptera parasitoid pada area perkebunan kelapa sawit PTPN VIII Cindali, Kecamatan Ranca Bungur, dan (2) mengetahui fluktuasi parasitoid penting yang terdapat pada area perkebunan kelapa sawit PTPN VIII Cindali, Kecamatan Ranca Bungur.

\section{METODE PENELITIAN}

Tempat dan Waktu. Penelitian dilaksanakan di perkebunan kelapa sawit PTPN VIII Afdeling 1 Cindali, Kecamatan Ranca Bungur, Kabupaten Bogor, Provinsi Jawa Barat. Pelaksanaan penelitian dilakukan pada bulan September 2014 - Juni 2015. Identifikasi sampel dilakukan di Laboratorium Biosistematika Serangga, Departemen Proktesi Tanaman, Fakultas Pertanian, Institut Pertanian Bogor.

\section{Penentuan Plot Pengamatan pada Masing-masing}

Blok. Penelitian ini dilaksanakan selama 8 bulan dengan pengambilan sampel serangga pada area penelitian satu bulan sekali. Interval pengambilan sampel tersebut disesuaikan dengan kegiatan pemotongan pelepah kelapa sawit yang dilakukan oleh PTPN VIII. Penelitian dilakukan di 6 blok yang masing-masing luasnya 168250 ha yang dipilih secara acak sistematis sehingga cukup mewakili secara keseluruhan kebun kelapa sawit di daerah tersebut. Pada setiap blok penelitian dipilih 5 plot yang masing-masing berisi $5 \times 5$ pohon kelapa sawit yang ditentukan secara diagonal (Gambar 1). Jarak antara pohon kelapa sawit adalah 9,8 m. Dengan demikian satu plot berukuran 39,2 × 39,2 m.

Pada setiap plot dilakukan pengambilan sampel serangga Hymenoptera parasitoid dengan menggunakan metode perangkap nampan kuning, sweeping dan dengan pengamatan dan pengambilan hama secara langsung. Pengambilan hama dilakukan baik pada daun kelapa sawit maupun pada vegetasi bawah. Hama dipelihara dan dilihat apakah muncul parasitoid hama tersebut.

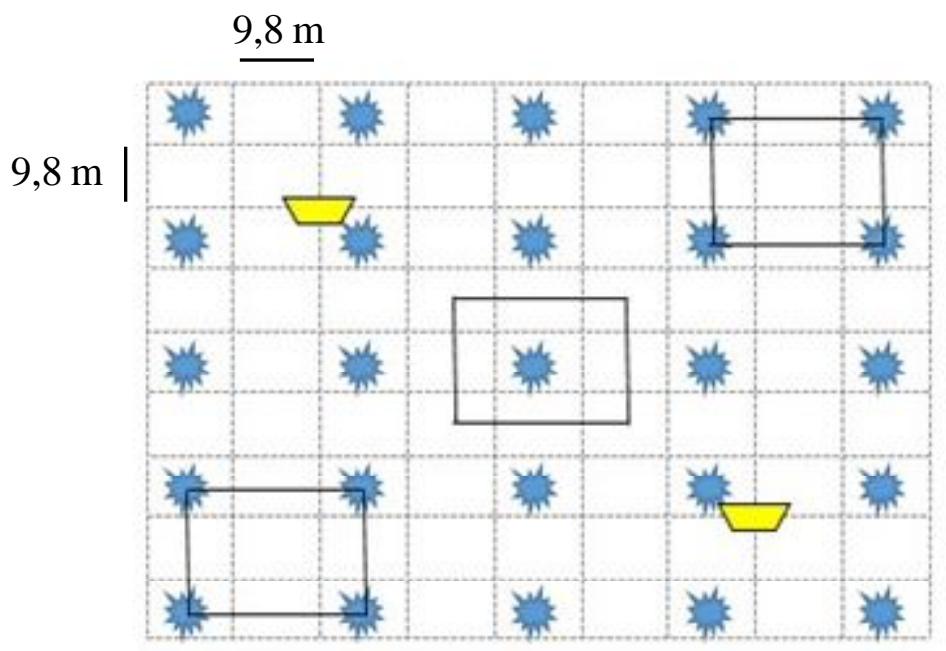

Gambar 1. Desain pengambilan sampel pada lahan kelapa sawit. 帏Kelapa sawit; $\square$ Perangkap namapan kuning; $\square$ Petak pengamatan tanaman vegetasi bawah 
Perangkap Nampan Kuning. Perangkap terbuat dari nampan yang berwarna kuning dengan ukuran 22 x 14 $\mathrm{x} 4 \mathrm{~cm}$ dan diisi larutan air sabun sampai batas setengah volumenya. Pada setiap blok dipasang 10 perangkap nampan kuning selama 1x24 jam. Serangga yang terperangkap disaring dan disortir. Kemudian Hymenoptera parasitoid diidentifikasi di laboratorium dengan menggunakan mikroskop stereo hingga tingkat morfospesies.

Sweeping Net. Pengambilan sampel serangga dengan sweeping net dilakukan pada pukul 07.30 WIB. Pada setiap plot dilakukan seratus kali ayunan ganda di atas tanaman penutup tanah. Hymenoptera parasitoid kemudian disortir dari serangga lain dan diidentifikasi di laboratorium sampai tingkat morfospesies.

\section{Pengamatan dan Pengambilan Hama dan} Parasitoid pada Kelapa Sawit. Pengamatan dan pengambilan hama pemakan daun kelapa sawit dilakukan pada 2 pohon kelapa sawit. Pada setiap pohon diamati 5 pelepah daun sehingga total dalam satu blok terdapat 50 pelepah daun kelapa sawit. Pada setiap daun kelapa sawit diamati ada tidaknya hama pemakan daun. Pada setiap plot dilakukan pemotongan satu pelepah daun kelapa sawit. Hama yang ditemukan pada daun yang dipotong dipelihara di laboratorium dan diamati Hymenoptera parasitoid yang keluar.

Analisis Data. Buku acuan yang digunakan dalam identifikasi adalah Hymenoptera of the World (Goulet \& Huber 1993), Annotated Keys to the Genera of Neartic Chalcidoidea (Gibson et al., 1997), dan A Handbook of the Families of Nearctic Chalcidoidea (Hymenoptera) (Grissell \& Schauff, 1990). Hasil identifikasi kemudian dianalisis untuk mengetahui tingkat keanekaragaman Hymenoptera parasitoid dengan menggunakan Indeks Shanon-Wienner (Magurran, 1998), dominansi dengan indeks Simpsons (Odum, 1971). Dinamika populasi parasitoid penting dihitung setiap morfospesies yang diperoleh per bulan. Hasil penghitungan tersebut kemudian dimasukkan ke dalam program Microsoft Excel 2010 untuk selanjutnya dibuat grafik agar dapat mengetahui fluktuasi yang terjadi pada parasitoid penting yang ditemukan.

\section{HASIL DAN PEMBAHASAN}

Keanekaragaman Hymenoptera Parasitoid. Nilai keanekaragaman dan kemerataan Hymenoptera parasitoid yang diperoleh menunjukkan bahwa area perkebunan kelapa sawit PTPN VIII Cindali memiliki nilai keanekaragaman yang tinggi. Hal ini ditunjukkan dengan nilai indeks Shanon-Wienner yang lebih besar dari 3.00 (Tabel 1). Nilai tertinggi dari indeks ShanonWienner didapat pada bulan Januari. Tingginya Nilai H pada bulan Januari dimungkinkan karena melimpah dan beragamnya inang yang tersedia bagi parasitoid tersebut. Semakin melimpah dan beragam inang yang tersedia bagi parasitoid, maka semakin tinggi juga keanekaragaman parasitoid pada area perkebunan kelapa sawit tersebut. Nilai indeks Simpson menunjukkan dominansi spesies dalam ekosistem, pada area perkebunan kelapa sawit PTPN VIII Cindali tidak ditemukan adanya dominansi suatu spesies tertentu. Hal ini ditunjukkan dengan nilai indeks Simpson yang hampir mendekati 1 .

Hal ini diduga karena area penelitian yang digunakan termasuk ke dalam kelapa sawit yang berumur tua (tahun tanam 2002, 2003, 2004 dan 2005). Semakin tua umur kelapa sawit, maka akan mempengaruhi kondisi mikrohabitat yang terdapat di dalam area perkebunan tersebut. Semakin tua umur kelapa sawit, maka semakin banyak vegetasi bawah

Tabel 1. Nilai indeks Shannon-Wiener (H) dan indeks Simpson (D) pada tanaman kelapa sawit PTPN VIII Cindali

\begin{tabular}{lcc}
\hline \multicolumn{1}{c}{ Bulan } & H & D \\
\hline September 2014 & 3,15 & 0,97 \\
Oktober 2014 & 3,41 & 0,97 \\
November 2014 & 3,47 & 0,97 \\
Desember 2014 & 3,16 & 0,97 \\
Januari 2015 & 3,69 & 0,95 \\
Februari 2015 & 3,69 & 0,96 \\
Maret 2015 & 3,65 & 0,96 \\
April 2015 & 3,57 & 0,95 \\
\hline
\end{tabular}


yang terdapat di dalamnya. Vegetasi bawah berguna sebagai tempat berlindung parasitoid dari musuh alami maupun iklim yang tidak mendukung kehidupan parasitoid tersebut (Wratten et al., 2004). Semakin banyak vegetasi bawah yang terdapat di dalam suatu area perkebunan kelapa sawit, maka semakin banyak sumber nutrisi dan inang alternatif yang dapat digunakan oleh parasitoid untuk dapat melangsungkan kehidupannya (Putra et al., 2012). Menurut Erwin (1990), pada hutan tropik, banyaknya kanopi memengaruhi keanekaragaman spesies. Semakin banyak kanopi yang terdapat pada suatu habitat, maka semakin banyak keanekaragaman spesies yang terdapat pada habitat tersebut.
Famili Scelionidae merupakan famili dengan jumlah individu terbanyak yang ditemukan, sedangkan famili Braconidae merupakan famili dengan jumlah morfospesies terbanyak yang ditemukan (Tabel 2).

Menurut Sahari (2012) dan Hindarto (2015), parasitoid yang dikumpulkan pada kondisi habitat yang sama dan pada umur tanaman kelapa sawit yang sama akan memiliki nilai keanekaragaman dan komposisi spesies yang hampir serupa. Hal ini juga yang memungkinkan nilai indeks Shanon-Wienner memiliki nilai lebih dari 3,00 dan indeks Simpson memiliki nilai hampir mendekati 1 . Walaupun dari jumlah total morfospesies per famili menunjukkan bahwa anggota

Tabel 2. Kelimpahan jumlah morfospesies dan jumlah individu pada setiap famili yang ditemukan di perkebunan kelapa sawit PTPN VIII Cindali

\begin{tabular}{lcc}
\hline Famili Parasitoid & $\Sigma$ morfospesies & $\Sigma$ individu \\
\hline Scelionidae & 12 & 1496 \\
Braconidae & 14 & 1054 \\
Eulophidae & 12 & 720 \\
Diapriidae & 4 & 698 \\
Mymaridae & 4 & 310 \\
Platygastridae & 3 & 279 \\
Ceraphronidae & 5 & 242 \\
Elasmidae & 2 & 217 \\
Trichogrammatidae & 4 & 216 \\
Encyrtidae & 10 & 215 \\
Ichneumonidae & 9 & 148 \\
Eurytomidae & 3 & 87 \\
Eucoilidae & 3 & 68 \\
Eupelmidae & 2 & 66 \\
Pteromalidae & 4 & 57 \\
Chalcididae & 2 & 57 \\
Bethylidae & 2 & 55 \\
Aphelinidae & 3 & 51 \\
Evaniidae & 4 & 28 \\
Torymidae & 2 & 21 \\
Drynidae & 1 & 17 \\
Tiphiidae & 1 & 11 \\
Scoliidae & 2 & 5 \\
Eucharitidae & 1 & 4 \\
Mutilidae & 1 & 2 \\
Pompillidae & 11 & 125 \\
Jumlah & & \\
\hline & 1 & \\
\hline & 1 & 5 \\
\hline
\end{tabular}


famili Scelonidae memiliki jumlah relatif yang cukup tinggi dibandingkan dengan angota parasitoid dari famili lain, akan tetapi nilai indeks Shanon-Wienner dan Simpson menunjukkan nilai yang tinggi. Hal ini dikarenakan niche yang dimiliki antara anggota famili Scelionidae dan sebagian besar anggota Hymenoptera parasitoid lain yang ditemukan di area penelitian berbeda. Anggota famili Scelionidae kebanyakan merupakan parasitoid telur (Goulet \& Hubber, 1993), sedangkan kebanyakan anggota Hymenoptera parasitoid lain yang ditemukan merupakan parasitoid larva (Braconidae, Eucoilidae, Scoliidae), nimfa (Drynidae, Mutilidae) ataupun pupa (Chalcididae, Pteromalidae, Ichneumonidae) (Goulet \& Hubber, 1993). Beberapa anggota parasitoid merupakan hiperparasit pada parasitoid lainnya. Menurut Odum (1971), suatu spesies tidak akan saling berebut atau berkompetisi dengan spesies lainnya apabila mereka memiliki niche yang berbeda. Menurut Wyie \& Speight (2012), perbedaan habitat atau niche dan cara hidup memungkinkan terjadinya perbedaan tiap spesies dalam satu kelompok yang sama dalam mengeksploitasi sumber makanan yang sama.

Kelimpahan dan Komposisi Hymenoptera Parasitoid. Dari 26 famili yang ditemukan terdapat 5 famili dengan jumlah morfospesies dan individu yang lebih banyak dibandingkan famili lainnya. Kelima famili tersebut adalah Scelionidae, Braconidae, Eulophidae, Encyrtidae dan Ichneumonidae (Gambar 2). Kelima famili dengan jumlah morfospesies dan individu terbanyak tersebut, masing-masing terdapat morfospesies dengan jumlah individu yang dominan. Pada famili Scelionidae, morfospesies dengan jumlah individu tertinggi adalah Scelio sp 1, Bracon sp. pada famili Braconidae, Chrysocharis pentheus pada famili
A

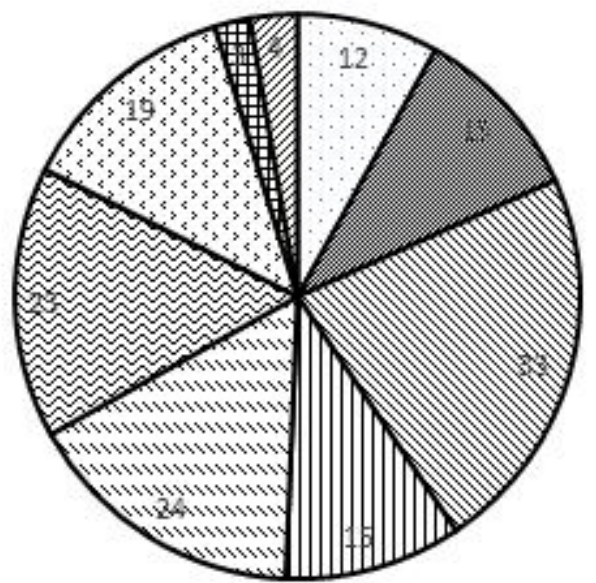

B

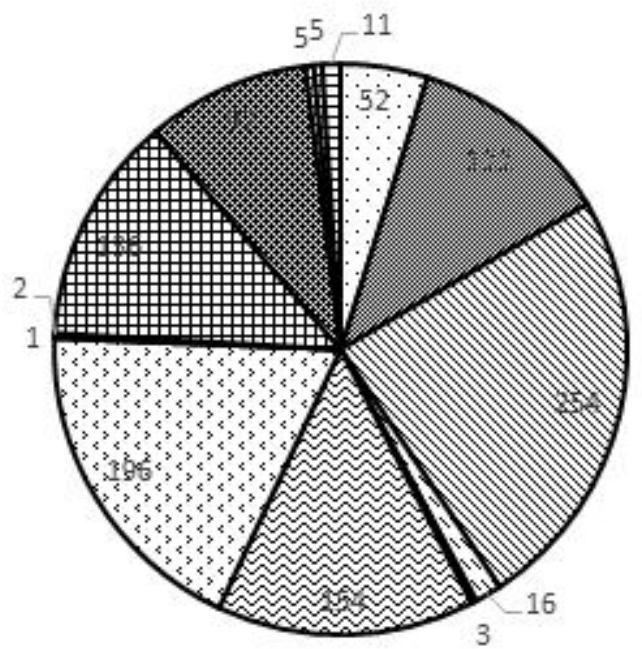

Charops bicolor

Chlorocrytus purpuratus

- Cosmoconus sp.

口 Eurycryptus sp.

ه Goryphus basilaris

E. Icneumon sp. 1

Icneumon sp. 2

由 Macrocentrus sp.

$\boldsymbol{0}$ Xanthopimpla flavolineata

Apanteles glomeratus

- Bracon sp.

- Cardiochiles saltator

ه Colastes sp.

Diachasmimorpha sp.

- Doryctobracon sp.

- Heterospilus sp.

- Meteorus sp.

由 Microplitis demolitor

* Microplitis manilae

- Fopius sp.

日 Spathius sp.

- Spinaria spinator 
C

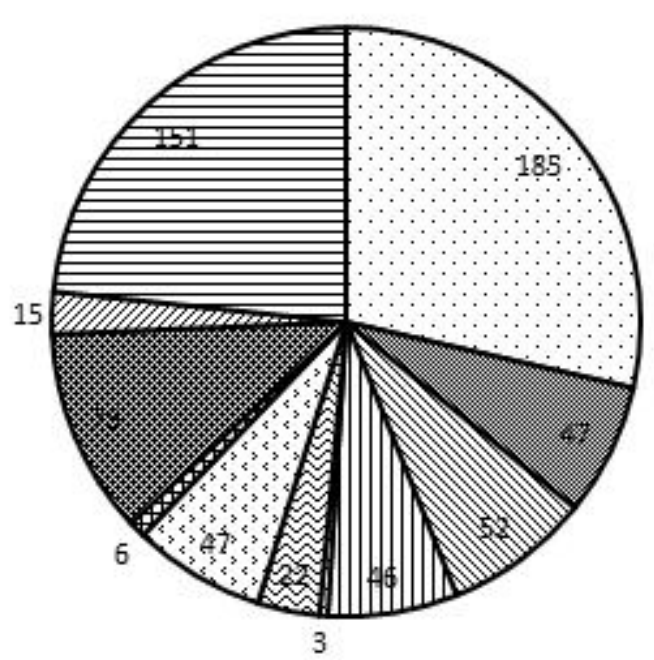

D

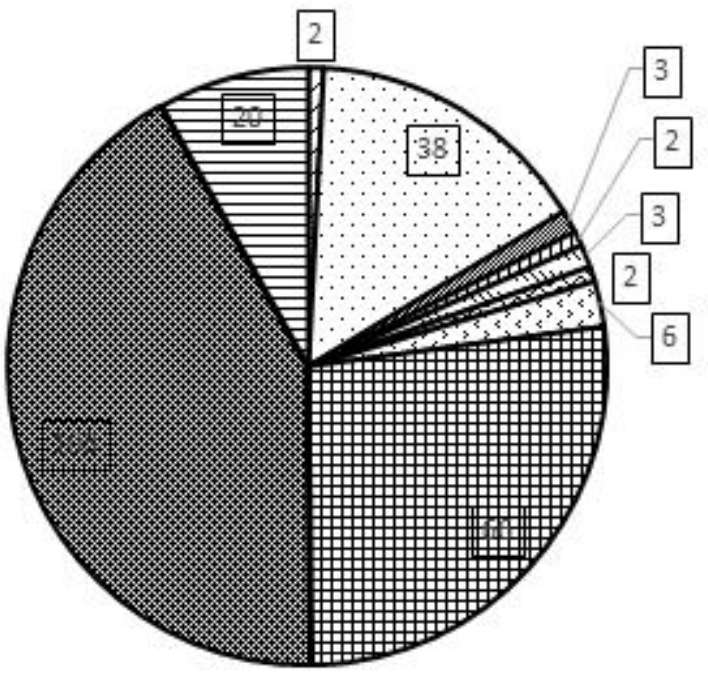

$E$

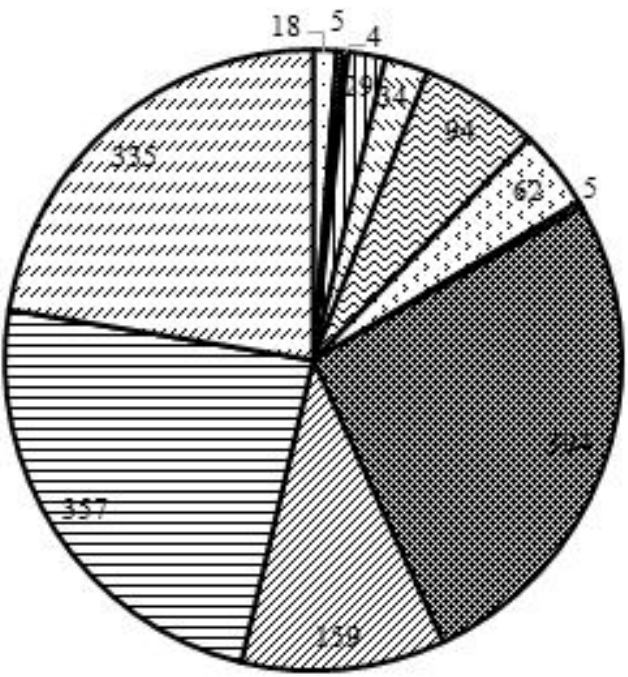

- Chrysocharis pentheus

… Chrysocharis walleyi

ه Closterocerus trifasciatus

( Diglyphus issaea

- Eulophus sp.

ब Euplectrus sp.

- Hemiptarsenus varicornis

田 Neochrysocharis sp.

* Pediobius sp.

口 Pnigalio sp.

- Tetrastichus schoenobii

7 Anagrus sp.

口 Copidosoma sp.

Encrytidae sp. 2

(I) Encrytidae sp. 4

ه Encrytidae sp. 5

* Hambletomia pseudococcina

- Leptomastix sp.

- Metaphycus sp.

凶 Microterys nieneri

- Ooencyrtus sp.

口 Trissolcus sp.

B Baeus sp.

ه Calloteleia sp.

- Ceratobaeus sp.

ब Gryon sp.

* Macroteleia gracilis

- Macroteleia spinitibia

- Platycelio sp.

$\mathbf{S}$ Scelio sp. 1

च Scelio sp. 2

- Telenomus podisi

- Telenomus sp. 1

Gambar 2. Komposisi kelimpahan morfospesies pada famili (A) Ichneumonidae; (B) Braconidae; (C) Eulophidae; (D) Encyrtidae; (E) Scelionidae 
Eulophidae, Microterys nietneri pada famili Encyrtidae dan Cosmoconus sp. pada famili Ichneumonidae. Tingginya morfospesies tersebut diduga karena banyaknya inang yang ditemukan pada lokasi penelitian. Parasitoid Scelio sp. 1 memiliki jumlah individu yang tinggi karena banyaknya ordo Orthoptera, dan Microterys nietneri memiliki inang berupa famili Coccidae seperti dari genus Ceroplastes atau Coccus (Abd-Rabou, 2012) atau scale insect lainnya. Cosmoconus sp. sendiri memiliki inang yang berupa larva dari Hymenoptera symphyta atau larva dari Ordo Lepidoptera (Goulet \& Hubber, 1993).

Faktor lain yang memengaruhi tingginya jumlah individu adalah iklim. Iklim terutama temperatur dapat memengaruhi keberhasilan suatu organisme untuk menetap, tumbuh dan berkembang pada suatu habitat (Hatherly et al., 2005). Temperatur selama penelitian rata-rata berkisar $25,9^{\circ} \mathrm{C}$. Menurut Gunduz \& Gulel (2005), parasitoid Bracon hebetor dapat hidup lebih optimal pada temperatur lingkungan berkisar antara 26 $\pm 2^{\circ} \mathrm{C}$, sedangkan Chrysocharis pentheus memiliki temperatur yang optimum bagi perkembangan parasitoid ini adalah sekitar $22^{\circ} \mathrm{C}$ (Mafi \& Ohbayashi, 2010) atau $20^{\circ} \mathrm{C}$ (Sugimoto et al., 1981).

Fluktuasi Hymenoptera Parasitoid Penting. Fluktuasi Hymenoptera parasitoid penting yang terdapat pada area perkebunan kelapa sawit PTPN VIII mengikuti fluktuasi inangnya (Gambar 3). Beberapa hama pemakan daun kelapa sawit yang ditemukan sebagai inang adalah Metisa plana (Lepidoptera: Psychidae), Mahasena corbeti (Lepidoptera:
Psychidae), Setora nitens (Lepidoptera: Limacodidae), Birthosea bisura (Lepidoptera: Limacodidae), Ambadra sp. (Lepidoptera: Notodontidae) dan Pseudococcus sp. (Hemiptera: Pseudococcidae). Semakin banyak inang bagi parasitoid, maka semakin banyak parasitoid yang terdapat pada area tersebut. Selain itu faktor iklim dan vegetasi selama penelitian juga memengaruhi fluktuasi dari parasitoid penting pada area penelitian. Tingginya curah hujan akan semakin memengaruhi keanekaragaman vegetasi bawah pada perkebunan kelapa sawit PTPN VIII Cindali. Semakin beragamnya vegetasi bawah maka semakin beragam dan melimpah juga ketersediaan inang dan tambahan nutrisi bagi parasitoid tersebut.

Hubungan Antara Inang-Parasitoid. Dari pemeliharaan hama pemakan daun kelapa sawit, terdapat beberapa Hymenoptera parasitoid yang berasosiasi dengan hama tersebut. Parasitoid tersebut adalah Spinaria spinator, Aphanogmus sp., Charops bicolor, Telenomus podisi (Tabel 3). Terdapat satu parasitoid yang telah diketahui memarasit hama ulat Birthosea bisura yaitu Chlorocryptus purpuratus (Mariau, 1999) tetapi tidak ditemukan keluar dari ulat tersebut dalam pemeliharaan. Namun dalam pengambilan dengan menggunakan sweep net dan perangkap nampan kuning, ditemukan parasitoid tersebut. Hal ini menunjukkan bahwa musuh alami yang berupa Hymenoptera parasitoid yang terdapat dalam area perkebunan kelapa sawit PTPN VIII Cindali tergolong lengkap dan dapat memarasit semua instar dari hama kecuali fase dewasa.

A

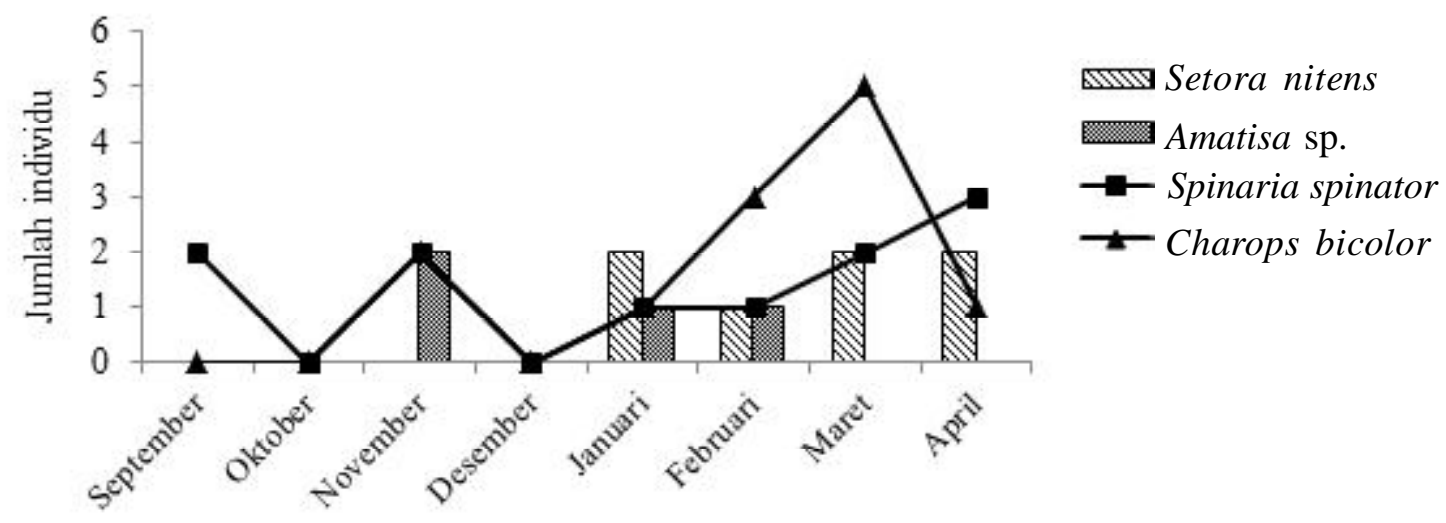

Bulan pengamatan 
B

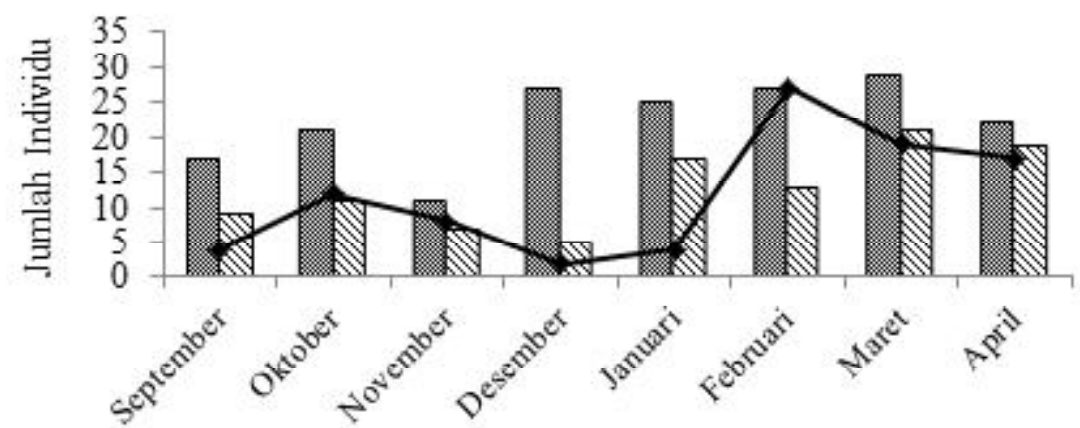

Metisa plana

Mाए। Mahasena corbetti

$\rightarrow$ Aphanogmus sp. 1

\section{Bulan pengamatan}

C
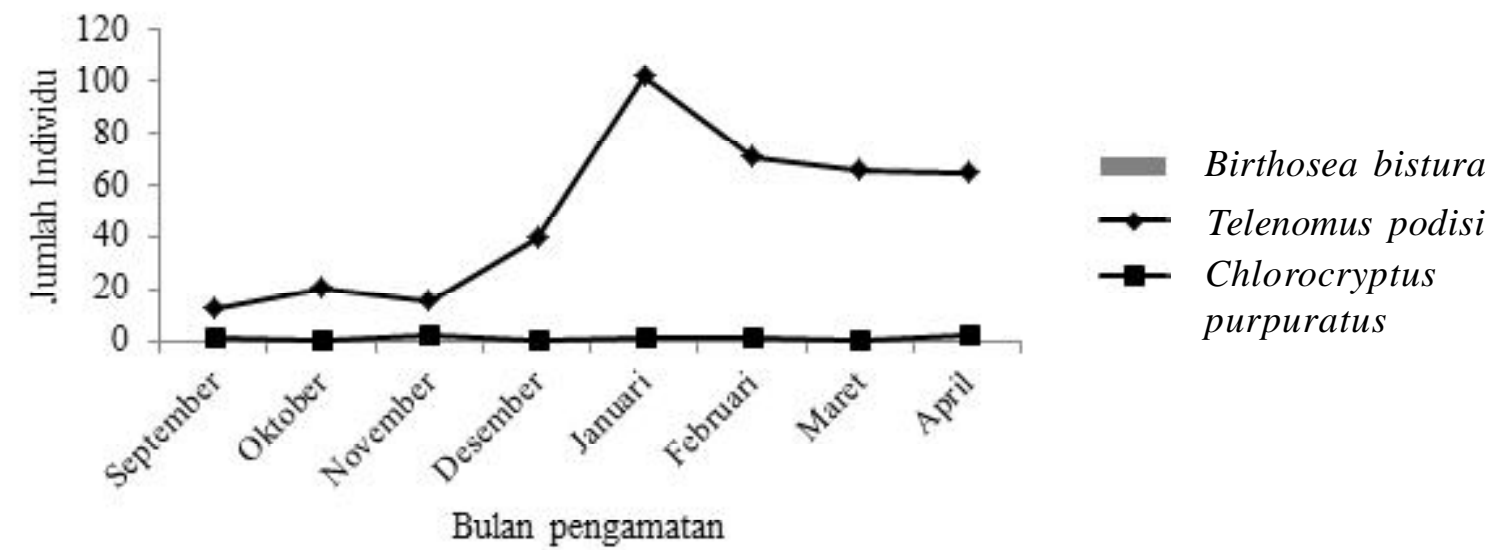

Gambar 3. Hubungan fluktuasi antara parasitoid-inang yang terdapat di area perkebunan kelapa sawit PTPN VIII Cindali (A) S. nitens dan Amatissa sp. dengan S. spinator dan C. bicolor (B) M. plana dan M. corbetti dengan Aphanogmus sp. (C) B. bisura dengan T. podisi dan C. purpuratus

Tabel 3. Hubungan antara Hymenoptera parasitoid dan inang pada tanaman kelapa sawit PTPN VIII, Cindali, Bogor

\begin{tabular}{llrrr}
\hline \multirow{2}{*}{ Parasitoid } & \multicolumn{1}{c}{ Inang } & \multicolumn{2}{c}{ Jumlah individu } & \multirow{2}{*}{$\%$} \\
\cline { 3 - 4 } & & PL & PTL & parasitisasi \\
\hline Spinaria spinator & Setora nitens & 6 & 11 & 85,71 \\
& Amatissa sp. & 3 & 11 & 75,00 \\
Charops bicolor & Setora nitens & 2 & 11 & 28,57 \\
Chlorocryptus purpuratus & Birthosea bisura & 0 & 15 & 0,00 \\
Telenomus podisi & Birthosea bisura & 50 & 394 & 76,92 \\
Aphanogmus sp. & Mahasena corbetti & 8 & 93 & 7,84 \\
& Metisa plana & 12 & 34 & 6,70 \\
Gryon sp. & Phintella sp. & 32 & 37,05 \\
Acerophagus sp. & Pseudococcus sp. & 8 & 2 & 3,83 \\
\hline
\end{tabular}

$\mathrm{PL}=$ pengamatan langsung, $\mathrm{PTL}=$ pengamatan tidak langsung 


\section{SIMPULAN}

Perkebunan kelapa sawit PTPN VIII Cindali, Bogor memiliki tingkat keanekaragaman Hymenoptera parasit yang tinggi dengan nilai indeks 3,399. Hymenoptera parasitod yang ditemukan terdiri dari 26 famili, 111 morfospesies dan 6125 individu, dengan morfospesies terbanyak yang ditemukan dari famili Braconidae sebanyak 14 morfospesies. Jumlah total individu tebanyak adalah Scelio sp. dari famili Scelionidae dengan 394 ekor. Parasitoid yang ditemukan berasosiasi dengan hama pemakan daun kelapa sawit adalah Spinaria spinator (Braconidae), Charops bicolor (Ichneumonidae), Aphanogmus sp. (Ceraphronidae), Telenomus podisi (Scelionidae) dan Chlorocryptus purpuratus (Ichneumonidae).

\section{SANWACANA}

Terimakasih saya ucapkan kepada Kepala PTPN VIII yang telah mengijinkan saya untuk dapat melakukan penelitian di perkebunan kelapa sawit PTPN VIII, Cindali, Bogor. Terimakasih juga saya ucapkan kepada Bapak Genta selaku Kepala afdeling I kebun kelapa sawit PTPN VIII yang telah memberikan ijin sehingga saya dapat melakukan penelitian di tempat tersebut.

\section{DAFTAR PUSTAKA}

Abd-Rabou S. 2012. New records of host insects and distribution of the effective parasitoid, Microterys nietneri Motschulsky (Hymenoptera: Encyrtidae) in Egypt. J. Trop. Asian Entomol. 1: 29-31.

Ayuningsih M. 2013. Frekuensi kunjungan Elaeidobius kamerunicus Faust. pada bunga betina dan efektivitasnya terhadap pembentukan buah kelapa sawit [Tesis]. Institut Pertanian Bogor, Bogor.

Erwin TL. 1990. Canopy arthropod biodiversity: a chronology of sampling techniques and results. Rev. Per Entomol. 32: 71-77.

Gibson GAP, Huber JT, \& Woolley JB. 1997. Annotated Keys to the Genera of Neartic Chalcidoidea (Hymenoptera). NRC Research Press. Ottawa, Canada.

Godfray HCJ. 1994. Parasitoid: Behavioral and Evolutionary Ecology. Pricenton University Press, New Jersey.
Goulet H \& Huber JT. 1993. Hymenoptera of the World: An Identification Guide to Families. Centre for land and Biological Resources Research, Ottawa.

Grissell EE \& Schauff ME. 1990. A Handbook of the Families of Nearctic Chalcidoidea (Hymenoptera). The Entomological Society of Washington, Washington.

Gunduz EA \& Gulel A. 2005. Investigation of fecundity and sex ratio in the parasitoid Bracon hebetor Say (Hymenoptera: Braconidae) in relation to parasitoid age. Turk. J. Zool. 29(4): 291-294.

Kusumawardhani G. 2011. Keanekaragaman serangga pengunjung bunga jantan kelapa sawit (Elaeis guineensis Jacq.) [Tesis]. Institut Pertanian Bogor, Bogor.

Hatherly IS, Hart AJ, Tullet AG, Bale JS. 2005. Use of thermal data as a screen for the establishment potential of non-native biological control agents in the UK. Biocontrol. 50(5): 687-698.

Hindarto A. 2015. Keanekaragaman serangga pada perkebunan kelapa sawit pada umur tanaman yang berbeda di unit Kebun Rambutan PTPN III [Tesis]. Institut Pertanian Bogor, Bogor.

Mafi Sh \& Ohbayashi N. 2010. Biology of Chrysocharis pentheus, an endoparasitoid wasp of the citrus leafminer Phyllocnistis citrella Stainton. J. Agr. Sci. Tech. 12(2): 145-154.

Magurran AE. 1998. Ecological Diversity and its Measurement. Princeton University Press, New Jersey.

Mariau D. 1999. Limacodidae (Lepidoptera) on oil palm and coconut, harmful species and natural enemies. Retour. Au. Mепи. Plantations, Recherche. Develop. 6(3): 149-160.

Odum EP. 1971. Fundamentals of Ecology. WB Saunders Company, Philadelphia.

[PDI] Pusat Data dan Informasi. 2007. Gambaran Sekilas Industri Kelapa Sawit. Departemen Perindustrian, Jakarta.

Putra ETS, Simatupang AF, Supriyanta SW \& Indradewa D. 2012. The growth of one-year old oil palm intercropped with soybean and groundnut. $J$. Agric. Sci. 4(5): 169-180. 
Sahari B. 2012. Struktur komunitas parasitoid Hymenoptera di perkebunan kelapa sawit, Desa Pandu Senjaya, Kecamatan Pangkalan Lada, Kalimantan Tengah [Disertasi].Institut Pertanian Bogor, Bogor.

Syed RA \& Shaleh HA. 2003. Integrated pest management of bagworms in oil palm plantations of PTPP London Sumatra Indonesia TBK (with particular reference to Mahasena corbetti Tams) in North Sumatra (Indonesia). Diakses pada 4 September 2014.
Wratten S, Berndt L, Tylianakis J, Ernando P, \& Didham R. 2004. Adding flora diversity to enhance parasitoid fitness and eficacy. Diakses pada 9 Januari 2015. 